\title{
Adoption of Conservation Agriculture in Bangladesh: Problems and Prospects
}

\author{
Aurup Ratan Dhar ${ }^{1, *}$, Md. Monirul Islam, Jasim Uddin Ahmed ${ }^{2}$ \\ ${ }^{1}$ Department of Agricultural Economics, Bangladesh Agricultural University, Mymensingh, Bangladesh \\ ${ }^{2}$ Department of Agricultural Economics and Policy, Sylhet Agricultural University, Sylhet, Bangladesh \\ *Corresponding author: aurup971@gmail.com
}

\begin{abstract}
The research was conducted to evaluate the problems and prospects of adopting conservation agriculture in Jamalpur and Bogra districts of Bangladesh. A total of 120 farmers (20 from focal and 100 from control group) were surveyed for collecting necessary data and information. A combination of descriptive statistics and mathematical techniques was used to analyze the data. Focal farmers followed the basic principles of conservation agriculture but control farmers continued conventional crop farming practices. Focal farmers were more profitable compared to control farmers in terms of wheat and bean production. Less production due to minimum tillage, difficulties in maintenance, lack of extension service etc. were the major problems faced by the farmers. Knowledge on soil conservation and soil quality improvement, use of organic fertilizer, etc. were found as strengths; management of crop residue, scarcity of cowdung, etc. were found as weaknesses; labor opportunities, market demand, etc. were found as opportunities; and climate change and price fluctuation were found as threats of adopting conservation agriculture. Regular extension contact, arrangement of training programmes and input support are to be ensured by different government and non-government organizations to motivate farmers for adopting conservation agriculture practice.
\end{abstract}

Keywords: adoption, conservation, agriculture, problems, prospects

Cite This Article: Aurup Ratan Dhar, Md. Monirul Islam, and Jasim Uddin Ahmed, "Adoption of Conservation Agriculture in Bangladesh: Problems and Prospects." World Journal of Agricultural Research, vol. 5, no. 5 (2017): 265-272. doi: 10.12691/wjar-5-5-3.

\section{Introduction}

Bangladesh is a role model for the United Nations to be showcased for its excellent development performance to developing nations in the field of agriculture. Soil fertility and crop productivity are reducing over the time in Bangladesh due to monoculture of cereal crops (mainly rice) [1]. Introduction of conservation agriculture plays a vital role in increasing organic matter content in soil and in reducing soil erosion. It is a modern agricultural practice which is gaining popularity in many parts of the world. Conservation agriculture is characterized by a number of components which are: (i) minimum tillage operation for seedbed preparation, (ii) maintaining crop residues covering the soil, (iii) incorporating a cover crop in the rotation cycle and (iv) using organic fertilizers and integrated pest management technologies [2,3,4]. It aims to make better use of agricultural resources through the integrated management of available soil, water and biological resources, combined with limited external inputs. It offers an opportunity for arresting and reversing downward spiral of resource degradation, decreasing cultivation costs and making agriculture more resource-use-efficient, competitive and sustainable by maintaining a permanent or semi-permanent organic soil cover, crop rotation and minimum soil disturbance [5]. Crop production profitability under this farming practice tends to increase over time relative to conventional agriculture. In economic terms, conservation agriculture performs better than tillage-based farming. Three or four years crop rotations can reduce the use of nitrogen fertilizer and pesticide. The labour inputs in this farming practice could be reduced by $75 \%$ [6].

Modalities of such farming have been described in a good number of literatures in the global context $[7,8,9]$ as well as in the context of Bangladesh [10,11]. Although conservation agriculture aims to help farmers to earn more income with reduced amount of labour, irrigation and other high energy external input costs; keep land healthy and productive; and conserve natural environment [12]; about $8-10 \%$ farmers around the world follow this practice [13,14]. Despite these apparent advantages and a few notable exceptions in the developing world, conservation agriculture practice has spread relatively slowly, especially in farming systems in temperate climates. The transformation from conventional agriculture practice to conservation agriculture practice seems to require considerable farm management skills and involves investment in new equipment. It may also require minimum levels of social capital to foster its expansion. There is also policy debate on whether conservation agriculture can ensure better 
sustainability and livelihood enhancement of the resource poor farmers.

In light of this situation, this research aimed to identify the problems and possible opportunities of conservation agriculture practice, and suggest policy recommendations. The specific objectives of the study are: i) to estimate the profitability of crop farming following conservation agriculture practice; ii) to identify the problems regarding adoption of conservation agriculture; and iii) to scrutinize the prospects of adopting conservation agriculture in Bangladesh.

\section{Materials and Methods}

\subsection{Study Areas and Sample Size}

The study was conducted in two districts of Bangladesh which were: Jamalpur (major crop: wheat) and Bogra (major crop: bean). Two categories of farmers were targeted for investigation namely, focal farmers (farmers practicing conservation agriculture only) and control farmers (farmers practicing traditional agriculture only). In each locale of the study, a total of 60 farmers (10 focal and 50 control) were selected; of which focal farmers were selected purposively and control farmers were selected randomly. Thus, a total of 120 farmers were included as the sample for observation and data collection. Primary data were collected through questionnaire survey, focus group discussion (FGD) and key informant interview (KII) with local stakeholders. Secondary sources of data in the form of handouts, reports, publications, notifications, etc. having relevance with this study were also consulted.

\subsection{Analytical Techniques}

A combination of descriptive statistics (i.e., sum, averages, percentages, etc.) and mathematical techniques (problem confrontation index) was used to achieve the objective of the study. Problems of adopting conservation agriculture practice were analyzed with problem confrontation index (PCI). An overall score of the problems faced by the focal and control farmers were computed for each farmer by adding their scores of the problems in all 13 selected problems. Each farmer was asked to indicate the extent of difficulty caused by each of the problems by checking any of the four responses such as 'frequently, 'occasionally, 'rarely and 'not at all', and weights were assigned to these responses as 3,2, 1 and 0 , respectively. A problem confrontation index (PCI) for each 13 selected problems was computed by using the following formula:

$$
\begin{aligned}
\mathrm{PCI}= & \left(\mathrm{P}_{\text {frequently }} \times 3\right)+\left(\mathrm{P}_{\text {occasionally }} \times 2\right) \\
& +\left(\mathrm{P}_{\text {rarely }} \times 1\right)+\left(\mathrm{P}_{\text {not at all }} \times 0\right)
\end{aligned}
$$

Where, $\mathrm{P}_{\text {frequently }}=$ Number of responses indicating the problem occurred frequently; $\mathrm{P}_{\text {occasionally }}=$ Number of responses indicating the problem occurred occasionally; $\mathrm{P}_{\text {rarely }}=$ Number of responses indicating the problem occurred rarely; and $\mathrm{P}_{\text {not at all }}=$ Number of responses indicating no problem at all.
SWOT analysis was done to identify the problems and potentials of conservation agriculture practice. A SWOT analysis guides to identify the positives and negatives inside of the organization (S-W) and outside of it in the external environment (O-T). Finally, suggestions and recommendations were provided with by the author in the form of recommendation matrix for expanding conservation agriculture that will be synchronized for policy options.

\section{Results and Discussion}

\subsection{Diffusion of Innovation}

Worldwide evidence has recurrently exposed that conservation agriculture could counterbalance the aspects of soil degradation and water miss-use, help producers to meet the challenge of a more efficient use of land and water and derive higher level of income. The basic components of this farming practice are not site specific, but the most critical objectives of such practice allow extending the technology efficiently across a wide range of production conditions. Conservation agriculture is, therefore, considered an innovation process with the aim of modifying conventional crop production technologies with the use of appropriate apparatuses and contraptions.

Diffusion of innovations seeks to explain how, why and at what rate new ideas and technologies spread through cultures. Diffusion is a social process through which innovations are introduced into an organization or social group. Things that are spread through diffusion include ideas, values, concepts, knowledge, practices, behaviours, materials and symbols. Innovation is the successful exploitation of new ideas. Communication is the two-way process of reaching mutual understanding, in which participants not only exchange information, news, ideas and feelings but also create and share meaning. The innovation-decision process regarding adoption of conservation agriculture was consisted of five stages: i) knowledge, ii) persuasion, iii) decision, iv) implementation, and $\mathrm{v}$ ) confirmation.

A farmer was first exposed to the innovation with lack of information about the innovation. During knowledge stage, the farmer had not been inspired to find out more information about the innovation. The farmer was interested in the innovation and actively searched related information/details in persuasion stage. In the stage of decision, the farmer took the concept of the change, weighed the advantages/disadvantages of using the innovation and decided whether to adopt or reject the innovation. The farmer employed the innovation to a varying degree depending on the situation. During implementation stage, the farmer also determined the usefulness of the innovation and searched for further information about it. The farmer finalized the decision to continue using the innovation in confirmation stage which was the authentication of making the right decision.

\subsection{Adopter Categories}

An adopter category is a classification of individuals based on their willingness to try out a new innovation or new product. The categories of adopters were: innovators, 
early adopters, early majority, late majority and laggards [15].

Innovators are farmers who are willing to take risks, have the highest social status, have financial liquidity, are social, and have the closest contact to scientific sources and interaction with other farmers. Their risk tolerance allows them to adopt conservation agriculture that may fail ultimately. Early adopters have the highest degree of opinion leadership among the adopter categories; and have a higher social status, financial liquidity, advanced education and are more socially forward than late adopters. Early majority adopt the innovation taking a longer time for analysis than the innovators and early adopters. Their social status, contact with early adopters and opinion leadership are above average than others. Late majority adopt the innovation after the average participant. They approach the innovation with a high degree of scepticism and after the majority of society have adopted the innovation. Farmers in laggards category show little to no opinion leadership. These individuals typically have a tendency to be focused on traditions, lowest social status, lowest financial liquidity, oldest among adopters, and in contact with only family and close friends.

The author found that in case of adopting conservation agriculture practice, the percentages of innovators, early adopters, early majority, late majority and laggards were 5.0, 15.0, 30.0, 35.0 and 15.0\%, respectively. Although most of the farmers were dubious about adopting this practice at the beginning, ultimately the adoption of this practice was successful.

\subsection{Profitability of Crop Production}

A limited amount of input support (i.e., seeds/planting materials, manures and fertilizers, organic pesticides, care and management, etc.) were provided to the focal farmers at free of cost for 10.0 decimal land (command area) for cultivating crops following the principles of conservation agriculture. Control farmers did not receive any kind of input support or technical advice for practicing such farming and they produced crop following conventional crop farming.

The cost of producing one $\mathrm{kg}$ wheat and return from one $\mathrm{kg}$ wheat is shown in Table 1 . It is experienced that total output of wheat was decreased by $10 \mathrm{~kg}$ in case of focal farmers after adopting conservation agriculture, but in case of control farmers, it was increased by $20 \mathrm{~kg}$. The reasons behind the decrease in crop production of focal farmers were reduced tillage and no use of synthetic energy inputs. It is also evident that focal farmers had reduced the cost of producing per kg wheat from Tk. 11 to Tk. 9, i.e., by Tk. 2 after adopting conservation agriculture practice whereas the cost in case of control farmers was unchanged. Return per kg wheat was increased by Tk. 3 (i.e., from Tk. 13 to Tk. 16) in terms of focal farmers and in terms of control farmers, it was increased by Tk. 1 (i.e., from Tk. 12 to Tk. 13) after practicing conservation agriculture which clearly implies that profit of focal and control farmers per kg wheat was increased by Tk. 5 and Tk. 1, respectively during the research period (Table 1 ).

The cost of producing one $\mathrm{kg}$ bean and return from one $\mathrm{kg}$ bean is shown in Table 2. It is seen that total output of bean was increased by $50 \mathrm{~kg}$ in case of focal farmers and
$10 \mathrm{~kg}$ in case of control farmers after adopting conservation agriculture. It is also found that focal farmers had reduced the cost of producing per kg bean from Tk. 6 to Tk. 5, i.e., by Tk. 1 after adopting conservation agriculture practice whereas the cost in case of control farmers was unchanged. Return per kg bean was increased by Tk. 1 (i.e., from Tk. 8 to Tk. 9) in terms of both focal and control farmers after practicing conservation agriculture which clearly implies that profit of focal and control farmers per kg bean was increased by Tk. 2 and Tk. 1 , respectively (Table 2 ).

Table 1. Profitability Per Unit Final Product of Wheat

\begin{tabular}{|c|c|c|c|c|c|c|c|}
\hline \multirow{2}{*}{\multicolumn{2}{|c|}{ Particulars }} & \multicolumn{5}{c|}{ Farmers' categories } \\
\cline { 3 - 8 } & \multicolumn{3}{|c|}{ Focal } & \multicolumn{3}{c|}{ Control } \\
\cline { 3 - 8 } & Before & After & Difference & Before & After & Difference \\
\hline i. & Total output (kg) & 250 & 240 & -10 & 240 & 260 & 20 \\
\hline ii. & Total cost (Tk.) & 2761 & 2246 & -515 & 2733 & 2798 & 65 \\
\hline iii. & Net return (Tk.) & 3199 & 3750 & 551 & 2887 & 3357 & 470 \\
\hline iv. & $\begin{array}{c}\text { Cost/kg (Tk.) } \\
\text { (ii } \div \text { i) }\end{array}$ & 11 & 9 & -2 & 11 & 11 & 0 \\
\hline v. & $\begin{array}{c}\text { Return/kg (Tk.) } \\
\text { (iii } \div \text { i) }\end{array}$ & 13 & 16 & 3 & 12 & 13 & 1 \\
\hline vi. & $\begin{array}{c}\text { Profit/kg (Tk.) } \\
\text { (v - iv) }\end{array}$ & 2 & 7 & 5 & 1 & 2 & 1 \\
\hline
\end{tabular}

Table 2. Profitability Per Unit Final Product of Bean

\begin{tabular}{|c|c|c|c|c|c|c|c|}
\hline \multirow{2}{*}{\multicolumn{2}{|c|}{ Particulars }} & \multicolumn{5}{|c|}{ Farmers' categories } \\
\cline { 3 - 8 } & \multicolumn{3}{|c|}{ Focal } & \multicolumn{3}{c|}{ Control } \\
\cline { 2 - 8 } i. & $\begin{array}{c}\text { Total output } \\
\text { (kg) }\end{array}$ & 1270 & 1320 & 50 & 1290 & 1300 & 10 \\
\hline ii. & Total cost (Tk.) & 7572 & 7070 & -502 & 7413 & 7508 & 95 \\
\hline iii. & Net return (Tk.) & 9867 & 12508 & 2641 & 10212 & 11824 & 1612 \\
\hline iv. & $\begin{array}{c}\text { Cost/kg (Tk.) } \\
\text { (ii } \div \text { i) }\end{array}$ & 6 & 5 & -1 & 6 & 6 & 0 \\
\hline v. & $\begin{array}{c}\text { Return/kg (Tk.) } \\
\text { (iii } \div \text { i) }\end{array}$ & 8 & 9 & 1 & 8 & 9 & 1 \\
\hline vi. & $\begin{array}{c}\text { Profit/kg (Tk.) } \\
\text { (v - iv) }\end{array}$ & 2 & 4 & 2 & 2 & 3 & 1 \\
\hline
\end{tabular}

Synthetic fertilizers and medicine free products that were supplied by focal farmers in the market, gained higher consumer attraction compared to those of the products supplied by control farmers which made a comparative advantage for focal farmers to sell the product at higher price in the market. The results are faintly similar with [16] where the authors found that focal farmers were more profitable in crop farming compared to proximal and control farmers. References $[17,18]$ also stated about reduction in cost of production which is relevant to the findings.

\subsection{Problem Confrontation Index (PCI)}

The farmers of the study areas were asked to give their opinion on 13 selected problems which were identified during data collection period and after computing the PCI scores, the problems were ranked according to their PCI score. The computed PCI score of the 13 problems ranged from 41 to 53 (against a possible range from 0 to 60) for focal farmers and 204 to 258 (against a possible range from 0 to 300) for control farmers which were arranged in rank order according to their PCI scores as shown in Table 3. 
Table 3. Problem confrontation index including thirteen (13) selected problems

\begin{tabular}{|c|c|c|c|c|c|c|c|c|c|c|c|c|}
\hline \multirow[b]{3}{*}{ Identified problems } & \multicolumn{12}{|c|}{ Farmers' categories } \\
\hline & \multicolumn{6}{|c|}{ Focal $(n=20)$} & \multicolumn{6}{|c|}{ Control $(n=100)$} \\
\hline & 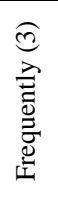 & 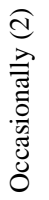 & 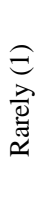 & 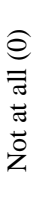 & $\vec{U}$ & 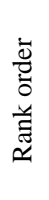 & 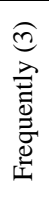 & 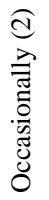 & 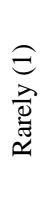 & 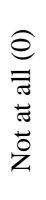 & $\widetilde{\varrho}$ & 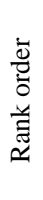 \\
\hline Lack of good quality inputs & 11 & 2 & 4 & 3 & 41 & 13 & 65 & 18 & 7 & 10 & 238 & 10 \\
\hline High price of inputs & 13 & 4 & 1 & 2 & 48 & 6 & 71 & 20 & 4 & 5 & 257 & 3 \\
\hline Lack of transportation and storage facilities & 12 & 3 & 4 & 1 & 46 & 8 & 59 & 17 & 20 & 4 & 231 & 11 \\
\hline Lack of knowledge on conservation agriculture practice & 11 & 3 & 3 & 3 & 42 & 12 & 72 & 10 & 9 & 9 & 245 & 6 \\
\hline Less production due to minimum tillage & 16 & 2 & 1 & 1 & 53 & 1 & 72 & 12 & 6 & 10 & 246 & 5 \\
\hline Weed infestation due to minimum tillage & 13 & 1 & 4 & 2 & 45 & 9 & 69 & 11 & 13 & 7 & 242 & 7 \\
\hline Outbreak of diseases & 10 & 5 & 4 & 1 & 44 & 10 & 53 & 16 & 16 & 15 & 207 & 12 \\
\hline Crop residues cannot be used as fuel & 12 & 1 & 5 & 2 & 43 & 11 & 57 & 11 & 11 & 21 & 204 & 13 \\
\hline Crop residues cannot be used as animal feed & 13 & 3 & 2 & 2 & 47 & 7 & 69 & 12 & 9 & 10 & 240 & 8 \\
\hline Crop rotation being a boring practice & 13 & 4 & 2 & 1 & 49 & 5 & 66 & 10 & 21 & 3 & 239 & 9 \\
\hline Lack of extension service & 15 & 2 & 2 & 1 & 51 & 3 & 70 & 19 & 10 & 1 & 258 & 2 \\
\hline Maintenance is difficult & 15 & 3 & 1 & 1 & 52 & 2 & 71 & 20 & 8 & 1 & 261 & 1 \\
\hline Insufficient institutional credit & 13 & 5 & 1 & 1 & 50 & 4 & 68 & 21 & 2 & 9 & 248 & 4 \\
\hline
\end{tabular}

Note: Calculation of PCI score for the problem of lack of good quality inputs-

PCI score of focal farmers $=(11 \times 3)+(2 \times 2)+(4 \times 1)+(3 \times 0)=41$

PCI score of control farmers $=(65 \times 3)+(18 \times 2)+(7 \times 1)+(10 \times 0)=238$

PCI scores for rest of the problems were computed accordingly.

\subsubsection{Lack of Good Quality Inputs}

Lack of good quality inputs was one of the major problems faced by the farmers in the research areas. Precisely, availability of good quality seeds and fertilizers were infrequent to the farmers. According to the perceptions of the farmers, the PCI score of this problem stood 41 and 238 in case of focal and control farmers, respectively which resulted in a rank of this problem as $13^{\text {th }}$ and $10^{\text {th }}$, accordingly.

\subsubsection{High Price of Inputs}

Majority of the farmers opined that the prices of the production inputs were very much higher for them to meet the production expense. The PCI score of this problem was 48 and 257 ranking by $6^{\text {th }}$ and $3^{\text {rd }}$ in terms of focal and control farmers, respectively (Table 3 ).

\subsubsection{Lack of Transportation and Storage Facilities}

Transportation of products was not easy for the farmers in the research areas because of underdeveloped road communication system. A vast amount of products were being damaged because of this reason. Also, storage facility was weak and as a result, storing of products for future sale was reasonably uncertain. This problem was ranked as $8^{\text {th }}$ and $11^{\text {th }}$ with PCI score of 46 and 231 according to focal and control farmers, respectively.

\subsubsection{Lack of Knowledge on Conservation Agriculture Practice}

Being a new dimension of crop farming, the practice of conservation agriculture was up-to-the-minute to the farmers. The knowledge of the farmers on this aspect was not immensely transparent. Lack of appropriate knowledge on this farming practice was a great knotty issue for the farmers. As stated by focal and control farmers, this problem was ranked as $12^{\text {th }}$ and $6^{\text {th }}$ by means of PCI score of 42 and 245, respectively (Table 3).
Reference [19] also found this farming practice as more complex than conventional agricultural practice.

\subsubsection{Less Production due to Minimum Tillage}

Soil tillage requirement for crop farming in Bangladesh does not permit minimum tillage in case of most of the crops which forestalls maximum crop production. The farmers of the research areas stated this as one of the major problems. The problem was ranked as $1^{\text {st }}$ and $5^{\text {th }}$ in accordance with the PCI score of 53 and 246 with the opinion of focal and control farmers, respectively. This problem is also highlighted by [20,21].

\subsubsection{Weed Infestation due to Minimum Tillage}

Another problem identified by the farmers was weed infestation because of less tillage than requirement. The PCI score of this problem was calculated at 45 and 242, which was ranked as $9^{\text {th }}$ and $7^{\text {th }}$ along with the statements of focal and control farmers, respectively.

\subsubsection{Outbreak of Diseases}

It was experienced by the farmers that the crop plants were affected by different kinds of diseases attributable to fungus and pests which hindered their crop production. The problem was severely faced by focal farmers who did not use any kind of synthetic pesticide or medicine. With the statements of focal and control farmers, the PCI score of this problem was determined as 44 and 207 which was ranked as $10^{\text {th }}$ and $12^{\text {th }}$, respectively (Table 3 ).

\subsubsection{Crop Residues Cannot be Used as Fuel}

The farmers of the research areas stated that the crop residue they left on the crop field could be effectively used as fuel. According to the perceptions of the farmers, the PCI score of this problem stood 43 and 204 in case of focal and control farmers, respectively which resulted in a rank of this problem as $11^{\text {th }}$ and $13^{\text {th }}$, accordingly. This problem was identified by [22] also. 


\subsubsection{Crop Residues Cannot be Used as Animal Feed}

Same as before, the crop residue could be used for feeding the livestock, opined by the farmers. This problem was ranked as $7^{\text {th }}$ and $8^{\text {th }}$ with PCI score of 47 and 240 according to focal and control farmers, respectively.

\subsubsection{Crop Rotation being a Boring Practice}

The choice of the suitable crop rotation was a boring practice according to majority of the farmers. Along with focal and control farmers' statements, the PCI score of this problem was found as 49 and 239 and they were ranked as $5^{\text {th }}$ and $9^{\text {th }}$, respectively (Table 3 ).

\subsubsection{Lack of Extension Service}

A noticeable number of farmers in the research areas stated that they experienced lack of extension contact. The frequency of visit by the extension agents in the research areas was very limited. The problem was ranked as $3^{\text {rd }}$ and $2^{\text {nd }}$ as per the PCI score of 51 and 258 according to focal and control farmers, respectively.

\subsubsection{Maintenance is Difficult}

The maintenance of conservation agriculture practice was seemed to be difficult than conventional farming practice to some of the farmers. As stated by focal and control farmers, this problem was ranked as $2^{\text {nd }}$ and $1^{\text {st }}$ by means of PCI score of 52 and 261, respectively.

\subsubsection{Insufficient Institutional Credit}

Inadequate credit facility was another major problem faced by the farmers in the research areas. The credit lending process of different formal credit lending institutions was not transparent to them and as a result, they had to depend on different informal sources of credit like moneylenders, relatives, friends, etc. The PCI score of this problem was calculated at 50 and 248, which was ranked as $4^{\text {th }}$ problem along with the statements of both categories of farmers (focal and control farmers) (Table 3).

The results are supported by [23] where the authors found high price of inputs, lack of institutional credit, lack of knowledge about conservation agriculture, etc. as the major problems faced by the farmers in the study areas.

\subsection{SWOT Analysis}

SWOT analysis of conservation agriculture is a scan of the internal and external factors that can have an impact on the strengths, weaknesses, opportunities and threats of adopting conservation agriculture (Table 4).

\subsubsection{Strengths of Practicing Conservation Agriculture}

The main strengths found in conservation agriculture practice are described and listed in the following section to provide an overview of the positive and outstanding factors contributing to a more efficient use of resources and better outcomes for farmers.

\section{Knowledge on soil conservation and soil quality improvement}

After adopting this farming system, 56.5 percent farmers had knowledge about soil conservation (Table 4). Farmers not only knew some of the consequences of a bad soil management but also the benefits of conserving it. Major problems according to the farmers were: lack of nutrients, lower yields and bad quality of crops. That knowledge favoured farmers and contributed positively to their farming practices. Farmers had implemented techniques and methods, such as contours and ridges to prevent rainfall to wash away fertilizers and seeds. They had also implemented other techniques to conserve the soil such as crop rotation and less use of chemical fertilizers. The positive and negative results due to the good or bad soil management had been an experience for the farmers. In addition to better and higher yields, farmers had noticed that land preparation became less hard which helped them to save effort and time. Reference [24] found that across growing seasons, soil water content under no-till was about $20 \%$ greater than under conventional tillage.

Table 4. SWOT Analysis Matrix

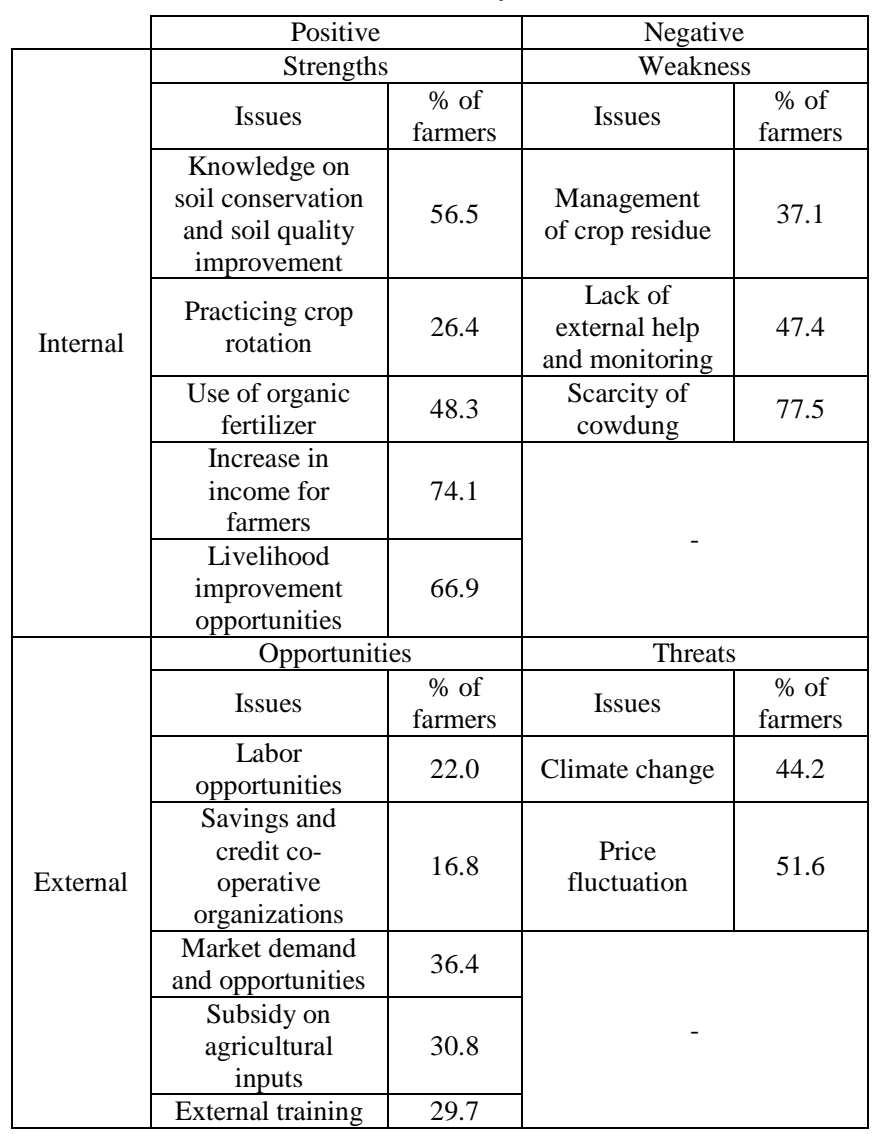

\section{Practicing crop rotation}

According to 26.4 percent farmers' testimonies, the use of crop rotation technique had brought some benefits to crop production such as better quality and higher amount of output. They stated that previously they did not use this technique, but they got some training from local NGOs where there were taught about benefits of crop rotation and which type of crops to plant. After this training, they had also noticed that amount of weeds had decreased, and soil could recover from previous seasons and get more nutrients.

\section{Use of organic fertilizer}

Before adopting conservation agriculture, farmers used to apply only synthetic fertilizers because they did not 
know about different benefits and the proper way to apply organic fertilizers. After adopting this farming practice, they used both synthetic and organic fertilizers, and after the successful results from using organic fertilizers, they stated that they would like to shift to use only organic fertilizers. 48.3 percent farmers stated that organic fertilizer provided with better yields and better quality of crops (Table 4). The shift to organic fertilizers from synthetic fertilizers had almost doubled the production for some farmers (supported by [25]). They had also experienced a big difference when preparing the soil for the next season. The soil became more workable and the amount of weed was low. According to the farmers, when using synthetic fertilizers, the nutrients and minerals from the soil were less which could be one of the causes for lower yields.

However, the demand for organic fertilizers was increasing and sometimes it was not enough to cover all the cultivating plots, therefore, they had to complement with synthetic fertilizers. Farmers became aware of the benefits of using organic fertilizers and consequences of using synthetic fertilizers. They had been looking for alternatives to reduce the amount of using synthetic fertilizers and to find solutions for the availability of organic fertilizers.

\section{Increase in income for farmers}

The farmers were positively influenced by the quality and quantity of the production. They could sell their products to a higher price and meet their needs. According to 74.1 percent farmers, the requirement of labour and synthetic fertilizers being lower in this farming system, farmers could save a remarkable amount of money and, therefore, invest that money in other income generating activities (Table 4). As time was also saved in this practice, farmers could engage themselves with other non-farming activities and earn a lucrative amount of money income. Increase in income also helped the farmers to invest in other sectors of agriculture like livestock, fishery and agroforestry.

\section{Livelihood improvement opportunities}

The livelihood condition of the farmers began to improve because of their higher income. 66.9 percent farmers were able to have better houses and improve livestock sheds. They had ensured access to clean and pure drinking water. The rate of child mortality and child undernourishment had been decreased. Farmers could send their children to school and ensure mandatory primary education. Availability of electricity among the farmers was also increased.

\subsubsection{Weaknesses of Practicing Conservation Agriculture}

The following weaknesses were considered as constraints affecting conservation agricultural practices that causing a negative impact on the farmers and their products.

\section{Management of crop residue}

Management of crop residue required additional and improved knowledge about other uses of crop residue besides using them for livestock feeding which was lacking among the farmers. Farmers in the research areas mainly collected crop residue for livestock feeding purposes. The residues from long distance lands were burned at the field. Majority of the farmers knew about consequences of burning crop residue to the soil. However, 37.1 percent farmers used this method because it was easier than to carry the crop residue to the household (Table 4). To carry them, they needed additional transportation, which implied additional workload as well as the use of valuable time during the day. A few farmers commented that agricultural officers together with local NGOs provided with some demonstrations about the use of crop residue but that was not adequate. Therefore, farmers did not have the opportunity to put in practice what they learnt and they could not see any benefit for it. Farmers preferred others to try first and prove that it worked before deciding to try themselves.

\section{Lack of external help and monitoring}

One of the major constraints found in the research areas was the lack of monitoring and supervision by the agricultural extension officers. According to the agricultural extension officers, the transportation system was not enough suitable to visit the areas to provide effective supervision and monitoring. Besides, there was shortage of extension staff to take care of this supervision. To improve the practice of conservation agriculture, farmers asked for more seminars and demonstration by GOs and NGOs. 47.4 percent farmers stated that usually when there were training seminars, only a few of them were invited or included. Farmers who usually participated, sometimes they did not share what they learnt. Therefore, they did not get new information. Farmers attributed this to the lack of organization.

\section{Scarcity of cowdung}

Most of the farmers applied cowdung as organic fertilizer to their crops. The result of applying cowdung was positive. However, a noticeable amount of farmers still used chemical fertilizers because of scarcity of cowdung. In the research areas, a small number of farmers had cows and so, the supply of adequate amount of cowdung was not possible. 77.5 percent farmers revealed that their only and easier option was to continue using chemical fertilizer though they knew about its consequences and low yields (Table 4).

\subsubsection{Opportunities of Practicing Conservation Agriculture}

Opportunities are external factors that are beneficial for the farmers which can contribute to the improvement and success of conservation agricultural practice.

\section{Labour opportunities}

Labour opportunities aroused since the required labour for agricultural activities decreased due to implementation of conservation agricultural. Therefore, farmers and other family members had the opportunity of working either in other lands or find other sources of employment in the local town or nearby. 22.0 percent farmers had the option of using bioslurry and IPM technology as an alternative to 
reduce workload in weed and pest management (Table 4). A few farmers had already used these technologies and they expressed that it reduced workload in fact, but it required additional knowledge on the correct doses, appropriate product, required equipment and timely use of it in order to be succeeded in this method. Reference [26] supported the result where the authors stated that compared to conventional tillage, average labour use across four alternative tillage and crop establishment options decreased by $25 \%, 40 \%$, and $33 \%$, respectively, for rice and maize, at the R-M system level.

\section{Savings and credit co-operative organizations}

16.8 percent farmers stated that savings and credit co-operatives were important assets for them. A number of NGOs in the research areas provided farmers with credit to buy their inputs and they provided the savings service which was a good opportunity for the farmers to save their profit and to have it available for the next season. These NGOs also provided facilities on payments so that farmers could borrow money to buy their inputs on time and a certain amount every month. Having access to credit facilitated this farming practice for the farmers.

\section{Market demand and opportunities}

Market can be seen as a great opportunity to guarantee the sale of the products of the farmers. The demand for organic agricultural products was higher in local, national as well as in the international market. The price was also higher because of the scarcity of organic products. Other marketing opportunity was through the co-operative groups. These co-operative groups bought all the production from the farmers who were members and they were in charge of selling them in the local market or to private buyers. The advantage was that members became sure to sell all their production. According to 36.4 percent farmers, the only disadvantage was that the co-operative groups needed a certain amount of initial fee as collateral in order to be a member (Table 4). However, other members stated that even though they had to pay, there was a risk they would not get any income.

\section{Subsidy on agricultural inputs}

In order to support the farmers and help them with some of the input expenses, the government had assigned subsidy programmes to cover some of these. The demand of inputs was high at the start of cropping season. Extension officers had the opportunity to make it sure that the inputs needed were available at that time. Thus, 30.8 percent farmers could have access to what they needed for a successful planting and harvesting, especially to perform these activities on time. Even though this subsidy did not cover all the inputs for every season, farmers stated that it was a small but significant support and they could save some money.

\section{External training}

External help from different GOs and NGOs was one of the most important opportunities for the farmers in the research areas. Local NGOs provided with practical demonstrations to the farmers to show the management of crop residue, maintenance of crop rotation and the use of organic fertilizers. They also provided special training and constant assessment, and worked directly in the land of the selected farmers to make them realize the results. Afterwards they could choose whether to adopt or not. 29.7 percent farmers showed their excitement and welcomed the demonstrators to teach them new agricultural methods (Table 4). These training programmes created a positive impact in adoption of conservation agriculture. Farmers, who had been part in training programmes before, were more likely to adopt new agricultural practices. Since the farmers had participated in these organizations, the opportunities to expand and introduce new practices were feasible.

\subsubsection{Threats of Practicing Conservation Agriculture}

Threats are external factors that can adversely affect the performance or achievement of the goals of conservation agricultural practice.

\section{Climate change}

44.2 percent farmers stated that they did not know when the first rainfall would come and so, they could not get ready for the preparation of land (Table 4). Sometimes the rainy season started after a long time of the expected period. Not only late rainfall but also the rainy season stopped before anticipated. Although it rained, the farmers did not know whether it would actually be enough to have a good harvest. Sometimes they had experienced consequences of unexpected extreme rainfall. This finding is similar with [27] where the authors identified most climatic variation in rainfall.

\section{Price fluctuation}

Market is considered as an important opportunity for the farmers to sell their production. However, price is a threat for the farmers. According to 51.6 percent farmers, sometimes the price of product was low but they had to sell their production even though the price would not cover their production cost (Table 4). For the majority of the farmers, selling products did not represent any profit. The lack of intervention from the government and the lack of organization among the farmers were considered as the core causes for that instability. According to the farmers, even though they had complaint about that to the extension officer, the issue had never been solved.

\section{Conclusion}

Findings of the research and the logical interpretation of their meaning in the light of other relevant facts enabled the researcher to draw some conclusions. Adoption of conservation agriculture practice in the study areas had a colossal impact on farmers' crop profitability. If focal farmers would continue following the principles of this practice, they would be more profitable in terms of crop production compared to control farmers. The study further identified a number of constraints, and internal and external prospects of adopting conservation agriculture in the study areas.

Keeping different internal and external factors in contrast, a set of policy actions is suggested by the 
researcher for the development of practicing conservation agriculture in the context of Bangladesh which is presented in the form of recommendation matrix (Table 5).

Table 5. Recommendation Matrix for Policy Connotation

\begin{tabular}{|c|c|c|c|}
\hline Facts of consideration & \multicolumn{2}{|c|}{ Recommendations } \\
\cline { 2 - 4 } & $\begin{array}{c}\text { Research } \\
\text { needed }\end{array}$ & $\begin{array}{c}\text { Extension } \\
\text { needed }\end{array}$ & $\begin{array}{c}\text { Policy } \\
\text { intervention } \\
\text { needed }\end{array}$ \\
\hline $\begin{array}{c}\text { Nourishment of farmers' knowledge } \\
\text { about conservation agriculture } \\
\text { practice }\end{array}$ & & $\sqrt{ }$ & \\
\hline $\begin{array}{c}\text { Involvement of government and non- } \\
\text { government organizations to provide } \\
\text { basic acquaintance to the farmers and } \\
\text { arrange training programmes }\end{array}$ & & $\sqrt{ }$ & \\
\hline $\begin{array}{c}\text { Regular extension contact from the } \\
\text { view point of extension agents }\end{array}$ & & $\sqrt{ }$ & $\sqrt{ }$ \\
\hline $\begin{array}{c}\text { Ensuring the availability of } \\
\text { agricultural inputs at the time of } \\
\text { requirement }\end{array}$ & & $\sqrt{ }$ & $\sqrt{ }$ \\
\hline $\begin{array}{c}\text { Enhancing direct input support as well } \\
\text { as input subsidy programmes }\end{array}$ & & $\sqrt{ }$ & \\
\hline $\begin{array}{c}\text { Providing farmers' access to modern } \\
\text { agricultural equipments to facilitate } \\
\text { conservation agriculture practice }\end{array}$ & $\sqrt{ }$ & $\sqrt{ }$ & \\
\hline $\begin{array}{c}\text { Inspiring the farmers to use organic } \\
\text { fertilizers instead of synthetic } \\
\text { fertilizers }\end{array}$ & $\sqrt{ }$ & $\sqrt{ }$ & \\
\hline $\begin{array}{c}\text { Creation of market with comparative } \\
\text { advantage of medicine free and } \\
\text { organic products }\end{array}$ & $\sqrt{ }$ & & \\
\hline $\begin{array}{c}\text { Restricting the use of synthetic } \\
\text { fertilizers, pesticides and medicine in } \\
\text { crop farming to a minimum limit with } \\
\text { a view to protect the environment } \\
\text { from being damaged }\end{array}$ & $\sqrt{ }$ & \\
\hline $\begin{array}{c}\text { Formation of savings and credit } \\
\text { cooperative groups which can ensure } \\
\text { the sale of the products of the member } \\
\text { farmers of the farmers to }\end{array}$ & & & \\
\hline
\end{tabular}

\section{References}

[1] Kafiluddin A and Islam MS. Fertilizer distribution, subsidy, marketing, promotion and agronomic use efficiency scenario in Bangladesh. Proceedings of IFA Crossroads Asia-Pacific 2008, held at Melbourne, Australia. Dec 16-18. 2008; 1-22.

[2] Kabir MH and Rainis R. Adoption and intensity of integrated pest management (IPM) vegetable farming in Bangladesh: An approach to sustainable agricultural development. Environment, Development and Sustainability. 2014; 17(6):1413-29.

[3] Vanlauwe B, Wendt J, Giller KE, Corbeels M, Gerard B and Nolte C. A fourth principle is required to define conservation agriculture in sub-Saharan Africa: The appropriate use of fertilizer to enhance crop productivity. Field Crops Research. 2014; 155:10-13.

[4] Lal R. A system approach to conservation agriculture. Journal of Soil and Water Conservation. 2015; 70(4):82A-88A.

[5] FAO. Food and Agriculture Organization of the United Nations. Rome, Italy. 2007.

[6] IFAD. International Fund for Agricultural Development, Via Paolo di Dono, Rome, Italy. 2005.

[7] USDA. Report and recommendations on organic farming. United States Department of Agriculture, Washington DC, USA. 1980.
[8] Lampkin N. Organic farming. Farming Press, Ipswich. 1990; 1-4.

[9] IFOAM. Basic standards for organic agriculture and processing. International Federation of Organic Agriculture Movements. 1996.

[10] Rahman MH. The influence of extension on the introduction of organic farming in Bangladesh. Litverlag Münster, Hamburg, London. 2001.

[11] Sarker MA and Itohara Y. Organic farming and poverty elimination: A suggested model for Bangladesh. Journal of Organic Systems. 2008; 3(1):68-79.

[12] Lampkin NH and Padel S. The economics of organic farming. An international perspective. Cab International, Oxon, UK. 1994.

[13] Parrott N, Olesen JE and Hogh-Jensen H. Certified and noncertified organic farming in the developing world. Global Development of Organic Agriculture: Challenges and Prospects. CAB International, Wallingford, Oxon. 2006; 153-176.

[14] Willer H, Yussefi M, Menzler and Sorensen N. The world of organic agriculture statistics and emerging trends 2008, main results. The World of Organic Agriculture, Bonn, Germany. 2008.

[15] Rogers EM. Diffusion of innovations, 4th edition. The Free Press, New York. 1995.

[16] Uddin MT, Dhar AR and Islam MM. Adoption of conservation agriculture practice in Bangladesh: Impact on crop profitability and productivity. Journal of Bangladesh Agricultural University. 2016; 14(1):101-112.

[17] Malik RK, Gupta RK, Singh CM, Yadav A, Brar SS, Thakur TC, Singh SS, Singh AK, Singh R and Sinha RK. Accelerating the adoption of resource conservation technologies in rice wheat system of the Indo-Gangetic plains. Proceedings of project workshop, Directorate of Extension Education, Chaudhary Charan Singh Haryana Agricultural University (CCSHAU), Hisar, India. 2005.

[18] RWC-CIMMYT. Rice-Wheat Consortium-International Maize and Wheat Improvement Center. Agenda notes, 13th regional technical coordination committee meeting, Dhaka, Bangladesh. 2005.

[19] Gupta R and Jat ML. Conservation agriculture: Addressing emerging challenges of resource degradation and food security in South Asia. Conservation Agriculture. 2010; 1-18.

[20] Derpsch R. Keynote: Frontiers in conservation tillage and advances in conservation practice. 10th International Soil Conservation Organisation meeting, Purdue University and USDA-ARS National Soil Erosion Research Laboratory, West Lafayette, Indiana. 2001.

[21] Hobbs PR and Govaerts B. How conservation agriculture can contribute to buffering climate change. CAB International, Wallingford, Oxon. 2010.

[22] Bhan S and Behera UK. Conservation agriculture in India Problems, prospects and policy issues. International Soil and Water Conservation Research. 2014; 2(4):1-12.

[23] Uddin MT, Dhar AR and Rahman MH. Improving farmers income and soil environmental quality through conservation agriculture practice in Bangladesh. American Journal of Agricultural and Biological Sciences. 2017; 12(1):55-65.

[24] De Vita P, Di Paolo E, Fecondo G, Di Fonzo N and Pisante M. No-tillage and conventional tillage effects on durum wheat yield, grain quality and soil moisture content in Southern Italy. Soil \& Tillage Research. 2007; 92:69-78.

[25] Hobbs PR and Gupta RK. Problems and challenges of no-till farming for the rice-wheat systems of the Indo-Gangetic plains in South Asia.ch6. 2004

[26] Gathala MK, Timsina J, Islam MS, Rahman MM, Hossain MI, Harun-Ar-Rashid M, Ghosh AK, Krupnik TJ, Tiwari TP and McDonald A. Conservation agriculture based tillage and crop establishment options can maintain farmers' yields and increase profits in South Asia's rice-maize systems: Evidence from Bangladesh. Field Crops Research. 2015; 172:85-98.

[27] Carvalho $\mathrm{M}$ and Lourenço E. Conservation agriculture - A Portuguese case study. Journal of Agronomy and Crop Science. 2014; 200: 317-324. 